Studies in African Linguistics

Volume 38, Number 1, 2009

\title{
A SKETCH OF AFITTI PHONOLOGY
}

\author{
Alex de Voogt \\ American Museum of Natural History
}

\begin{abstract}
Political conflict in the Sudan and the spread of Arabic are threatening Afitti, a North Eastern Sudanic language that has received relatively little scholarly attention. In addition to presenting original data on the language, this paper shows that Afitti is markedly different from Nyimang, its nearest linguistic neighbor, in respect to the absence of a third tone, the lack of a contrast between dentals and alveolars, the absence of distinctive vowel length, and its limited labialization.
\end{abstract}

\section{Afitti}

The Afitti language (Affitti, Dinik, Ditti, Unietti; ISO code aft) is spoken on the eastern side of Jebel el-Dair, a solitary rock formation in the North Kordofan province of Sudan (Maps 1 and 2; see also Bolton 1936; Kauczor 1923). Together with Nyimang (Nyima, Ama, nyi), this language is classified as Eastern Sudanic by Greenberg (1963). Rilly (2004) groups these two languages together with Nubian, Nara, Tama and Meroitic to constitute a subgroup of Eastern Sudanic, he called North Eastern Sudanic. Its closest linguistic neighbor is Nyimang, spoken west of Jebel el-Dair in the Nuba Mountains of South Kordofan (see also MacDiarmid \& MacDiarmid 1931; Rottland \& Jakobi 1991; Tucker \& Bryan 1956, 1966; Stevenson 1957, 1962, 1964, 1984).

The relatively small number of speakers, estimated at four thousand, as well as the longstanding conflict in Sudan, has resulted in this language receiving little to no attention, as compared to Nyimang. A notable exception to this lack of attention is the work of Robert C. Stevenson (Stevenson, Rottland \& Jakobi 1992), who collected materials in 1986-88, and whose work appeared posthumously in Bender 2000. Stevenson worked with a Dinik speaker in Khartoum. ("Dinik" is a 
word that covers both Afitti and Ditti, but is not commonly used to designate the language Afitti.) The differences between Afitti and Ditti are primarily lexical, and this study will focus on Afitti and discussing Ditti only tangentially, noting, however, words that are specific to only one dialect.

Afitti speakers, unlike speakers of the Ditti dialect, use an increasing number of Arabic loanwords. The high number of borrowings has made the collection of extensive wordlists of (etymologically) Afitti words challenging but not impossible. The limited number of speakers, the tensions in Sudan, and the dominant use of Arabic have progressively threatened the existence of the language. Thus, there were some problems with the collection of data.

Much of Stevenson's work on Afitti was published posthumously, largely unedited, in Bender (2000). Although Stevenson had concentrated on Nyimang during his stay in Sudan, he did perform some work on Afitti, this incomplete study remaining the most important publication on the language. With a similar background in the study of Nyimang, Claude Rilly conducted a short study of Afitti in 2007, which unfortunately remains unpublished. Unbeknownst to these linguists and to the present author at the time of his fieldwork, a phonology of Afitti had been published by Kauczor and Drexel in 1930. They spoke of the Daier language instead of Afitti or Dinik, but the variety they studied was surely Afitti. Many of the findings in this study that clash with the findings of Stevenson were first noted by Kauczor and Drexel.

\section{Sources of the Linguistic Data}

The research took place in Kundukur, one of the main Afitti villages at Jebel elDair, in January 2008 (see map 1). Words were collected following the Frankfurt Questionnaire for basic vocabulary, which was also used by Claude Rilly for Nyimang and for his preliminary study of Afitti. This wordlist largely overlaps with the SIL Comparative African Wordlist. Informants consisted of small groups of men who together answered questions through an interpreter from nearby elObeid (see map 2), who explained the words in the local dialect of Arabic. Variations in pronunciation were immediately apparent when they pronounced words individually. Recordings were made of these sessions.

One particularly knowledgeable informant, a 54-year-old brother of the local sheikh, accompanied the researcher to el-Obeid, where in the course of another week progress was made on the verbal system. On his return there was another session in a Ditti-speaking house, to ask for specific lexical items for which only Arabic words had been provided. There was ready agreement as to whether the lexical item was limited to Ditti speakers or was used by both groups. Recordings 
were made of words specific to the Ditti dialect.

\section{The Recent History of the Afitti and Ditti Speakers}

The Afitti live to the east of Jebel el-Dair. They previously resided at the foot of the mountain, but after the First World War overcrowding and increasing numbers of cattle drove the people down the mountain to the plane where they resettled on farms. These families from the mountain formed farming settlements largely in the same configuration as on the mountain and spread southeastward.

Map 1 shows the relative positions of the villages as they were found in 2008. The names and locations were provided by a local driver and several informants. Map 2 locates the research area in the wider region.

\section{Map 1. The Afitti research area}

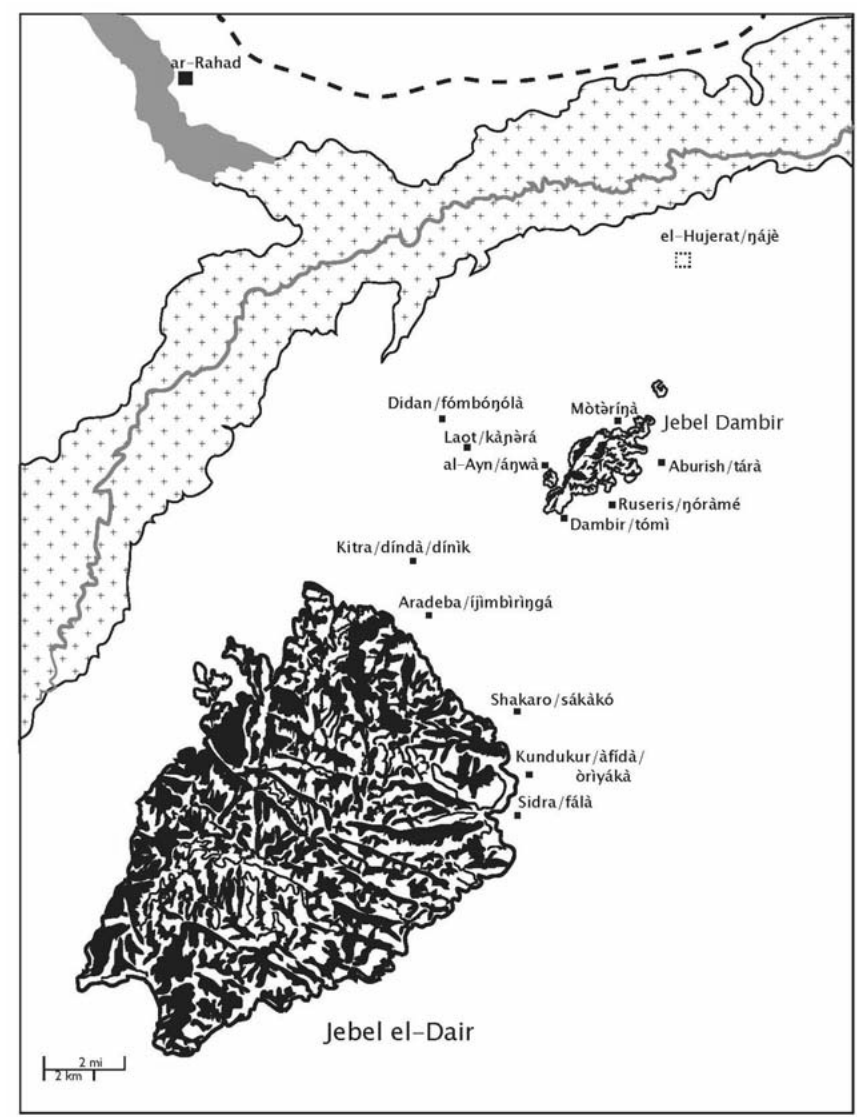


Map 2. The location of Jebel el-Dair in the region

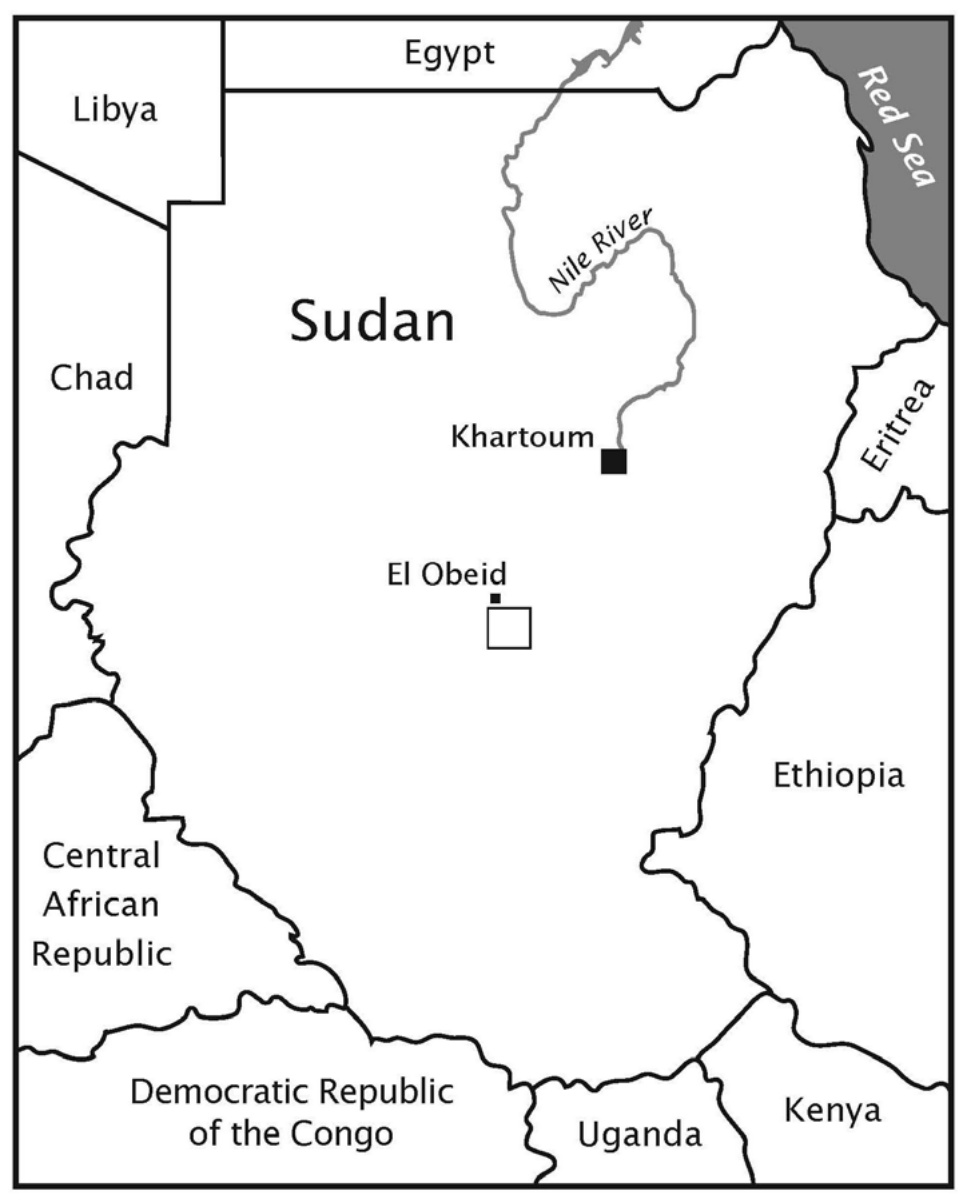

As a result of these movements the towns of Kundukur in the east, Sidra, towards the south, and Kitra in the north were established. Due to an increase in the number of cattle, a separate group was forced to settle at the foot of Jebel Dambir, further northeastwards. Cattle herders from Kitra settled to the northeast of Dambir and those from Kundukur and Sidra to the southwest. Today, the people of Kitra are known as "Ditti" and the others as Afitti, but the dialects have only minor lexical differences between them. Other groups identified by Kauczor in the 1930s were no longer recognized by the informants.

In 1966 the local inhabitants were rocked by a serious earthquake caused by volcanic activity inside Jebel el-Dair. People who lost their homes or feared further 
volcanic activity moved further northwards. With the help of the government they settled in a town that is now called el-Hujerat (Map 1).

Other natural events triggered further movements. When a drought struck the country in 1984, most of the cattle herders lost their livestock and became farmers. The draught also affected the cattle herders near Dambir so that today no Afitti or Ditti speakers herd cattle.

In the 1950s Islam entered the area and the process of conversion began; today all speakers of Afitti are considered Muslim. Arabic has become the main language of communication, particularly for the Afitti speakers, and the local school uses Arabic for teaching. Other external contacts have transformed the town of Sidra. It is now relatively modernized with stores, refrigerators and a police station, while the other villages remain without such facilities.

The change of occupation for the cattle herders, the modernization in Sidra, and the overall dominance of Arabic have combined to reduce the importance of Afitti and have led to decreasing speaker proficiency. Loanwords pervade the dialect, and it is only the Ditti who raise their children until school-going age without using Arabic.

The villages listed in Table 1 contain both Ditti and Afitti speakers. The villages do not have speakers of other languages within them. Nearby villages with speakers of other Nubian languages or Arabic are known but are not included here. Each of the listed villages has a local and a regional name, although in one case the regional name was not recorded. In some cases the local name is a translation of Arabic, and as can be seen, the word "Dinik", a name referring to both dialects, is also used for referring to the town of Kitra (line 5).

Table 1. Villages with Afitti or mainly Ditti (D) speakers in descending order of size

\begin{tabular}{|l|l|l|l|}
\hline Regional name* & Local name & Regional name* & Local name \\
\hline Kundukur & àfídà /òrìyákà & $\mathrm{n} / \mathrm{a}$ & mòtə̀ríjà $(\mathrm{D})$ \\
\hline Shakaro & sákàkó & Laot & kàjòrá \\
\hline Sidra & fálà & Ruseris & yóràmé \\
\hline El-Hujerat & yájè $(\mathrm{D})$ & Al-Ayn & ájwà \\
\hline Kitra & díndà / dínìk $(\mathrm{D})$ & Aradeba & ijìmbìrìngá \\
\hline Didan & fómbóyólà $(\mathrm{D})$ & Aburish & Tárà \\
\hline Dambir & tómì & & \\
\hline
\end{tabular}

* The spellings of the regional names were provided by the interpreter. 
Map 1 represents a revision of Bolton's map of Jebel el-Dair from 1936 that showed only Kundukur (spelled Gondukur), Sidra, and Kitra from the list above. It positions Jebel el-Dair and Jebel Dambir in relation to ar-Rahad, its adjoining lake, and an old railroad. Seasonal irrigation ditches and the green agricultural area surrounding them were added for further reference. The precise location of elHujerat is not shown since the information on its position north or northeast of Dambir was not sufficient to pinpoint its location.

\section{Differences between Afitti and Ditti}

The literature on Afitti sometimes speaks of "Dinik" and other times of "Afitti" (Bender 2000, Kauczor 1923, Stevenson 1984, Thelwall \& Schadeberg 1983). Only Drexel and Kauczor use "Daier" as the language name. The Afitti form only part of the group of speakers that collectively could be identified as Dinik speakers. Although the term "Dinik" can be used to designate the language, people in the villages more readily recognize the terms "Ditti" and "Afitti". Thus, speakers distinguish the two themselves.

The Ditti are limited to Kitra and some villages to the north and northwest of Dambir, but they have also intermarried with the Afitti so that a significant number of Ditti speakers can be found in villages dominated by Afitti speakers. The town of el-Hujerat, due to its history, is considered to have equal numbers of Ditti and Afitti speakers.

Speakers of the two dialects understand each other fully and the only linguistic differences are found in the lexicon. Impressionistic remarks include the overall feeling that Ditti people speak faster than speakers of Afitti, a feeling difficult to evaluate. Thus only the lexicon proved criterial for distinguishing the two. Oftentimes a word is used only by Ditti speakers for which Afitti speakers have a borrowing, commonly a word from Arabic but possibly from Kordofan Nubian as well. The Afitti speakers are alert to words unique to the Ditti group. Some of these are exemplified in Table 2.

Table 2. A comparison of Afitti and Ditti lexical differences

$\begin{array}{lll} & \text { Afitti } & \text { Ditti } \\ \text { 'forked pole/post' } & \text { kúrù } & \text { ùrtík } \\ \text { 'morning' } & \text { jígìl } & \text { tándìr } \\ \text { 'grasshopper' } & \text { fótà } & \text { làfîyá } \\ \text { 'taleh tree' } & \text { sèm } & \text { mé } \\ \text { 'broom' (of palm leaf) } & \text { éjèl } & \text { sál } \\ \text { 'mushroom' } & \text { ájísìk } & \text { kòrdésè }\end{array}$




$\begin{array}{lll}\text { 'walking stick' } & \text { mobórò } & \text { dŕ } \\ \text { 'hedgehog' } & \text { kínùkínùt } & \text { kúnàkúnà } \\ \text { 'badger' } & \text { ábúdòláf }(<\text { Arabic }) & \text { kókòr } \\ \text { 'flag' } & \text { rái }(<\text { Arabic }) & \text { kántìyá } \\ \text { 'baobab fruit' } & \text { òtòbóldì }(<\text { Arabic }) & \text { kàrtín }\end{array}$

\section{The Consonant System}

Table 3 displays the consonants of Afitti (identical with those of Ditti). Sounds in parentheses are of uncertain phonemic status.

Table 3. The Afitti consonant system

plosive voiced
plosive voiceless
fricative voiceless
nasal voiced
trill
lateral
semi-vowel

$\begin{array}{cccc}\text { bilabial } & \text { alveolar } & \text { palatal } & \text { velar } \\ \mathrm{b} & \mathrm{d} & \mathrm{j} & \mathrm{g} \\ & \mathrm{t} & \mathrm{c} & \mathrm{k} \\ \mathrm{f} & \mathrm{s} & & \\ \mathrm{m} & \mathrm{n} & \mathrm{j} & \mathrm{y} \\ & \mathrm{r} & & \\ & \mathrm{l} & & \end{array}$

(y)

Afitti has plosives and nasals at four places of articulation: bilabial, alveolar, palatal and velar. The plosives have a voicing contrast found primarily in wordinitial position. This distinction is largely lost in intervocalic position with neutralization in favor of the voiced variant, and most plosives are voiceless in final position due to a devoicing process affecting other sounds as well.

No words begin with a voiceless bilabial plosive. Final voiceless stops are often unreleased, but these variants occur in free variation with a released allophone. Dental and alveolar stops also appear in free variation; the dental variant appears with some speakers if they wish to stress or emphasize the consonant that is being pronounced. Nasals occur in all positions, including as syllabic nasals. They usually but not always assimilate to a following consonant. When a word-initial velar nasal follows a word-final, voiceless velar stop, the stop will be voiced and unreleased.

The liquids $/ \mathrm{r} /$ and $/ \mathrm{l} /$ share this tendency with the plosives of becoming devoiced in word-final position. For both $/ \mathrm{r} /$ and $/ 1 /$ their devoiced allophones can be easily mistaken for a fricative because of the heavy air flow. Like the nasals the liquids have a syllabic variant, although the syllabic /1/ is rare and unattested in word-initial position. Syllabic $/ \mathrm{r} /$, on the other hand, is common in the language 
and is found in monosyllabic words as well as in word-final position. As a consonant the central resonant $/ \mathrm{r} /$, as opposed to $/ 1 /$, however, is not found in wordinitial position and changes to a retroflex flap intervocalically. Whenever $/ \mathrm{r} /$ occurs in word-initial position, it is in clearly borrowed words from Arabic and other languages, words immediately identified as borrowings by Afitti speakers. The allophonic flap and $/ 1 /$ are easily confused but the flap can also be found immediately following a consonant (and preceding a vowel), a position where $/ 1 /$ is absent, one of the rare cases where a sequence of consonants can be found. The lateral liquid is found in word-initial, final and intervocalic position and is slightly palatalized; this palatalization leads to a slightly fricated voiceless palatal release with some speakers when it is found in word-final position.

Table 4 presents a set of forms containing many (near) minimal pairs.

\section{Table 4. Examples of Afitti (near) minimal pairs}

$\begin{array}{llll}\text { /òr/ } & \text { 'head' } & \text { /árà/ } & \text { '(upper) arm' } \\ \text { /ólò/ } & \text { 'tongue' } & \text { /járà/ } & \text { 'back' } \\ \text { /ómò/ } & \text { 'worm' } & \text { /tárà/ } & \text { 'house' } \\ \text { /dógò/ } & \text { 'chin' } & \text { /kárà/ } & \text { 'no!' } \\ \text { /jógò/ } & \text { 'chicken' } & \text { /kácà/ } & \text { 'narrow' } \\ \text { /sòró/ } & \text { 'friend' } & \text { /nàná/ } & \text { 'itch (rash)' } \\ \text { /tórò/ } & \text { '(bird) nest' } & \text { /sánà/ } & \text { 'iron' } \\ \text { /kórò/ } & \text { 'feather' } & \text { /tánè/ } & \text { 'ascend' } \\ \text { /kólò/ } & \text { 'God of locusts' } & \text { /tájè/ } & \text { 'broom' } \\ \text { /mbbórò/ } & \text { 'walking stick' } & \text { /gótì/ } & \text { 'shoulder' } \\ \text { /sórówà/ } & \text { 'wing' } & \text { /dàlà/ } & \text { 'many' } \\ \text { /nòròwá/ } & \text { 'ear' } & \text { /gàlá/ } & \text { 'red' } \\ \text { /yúnà/ } & \text { 'louse' } & \text { /bàtá/ } & \text { 'neck' } \\ \text { /kùná/ } & \text { 'mosquito' } & \text { /tógì/ } & \text { 'sleep/lie down' } \\ \text { /wùník/ } & \text { 'scorpion' } & \text { /gótì/ } & \text { 'shoulder' } \\ \text { /wùdíg/ } & \text { '(kursan) tree' } & \text { /bìbí/ } & \text { 'bumblebee' } \\ \text { /sál/ } & \text { 'broom'(Ditti) } & \text { /ìlílì/ } & \text { 'bell' } \\ \text { /fál/ } & \text { 'dancer' } & \text { /ánwà/ } & \text { 'eye' } \\ \text { /átá/ } & \text { 'hand' } & \text { /ángwà/ } & \text { 'maize porridge' }\end{array}$

The fricatives /f/ and /s/ are voiceless usually but sometimes vary with their voiced counterparts. They occur word initially and intervocalically, but only loanwords possess the fricatives in word-final position. As noted by Bender when publishing Stevenson's wordlist, the /s/ is sometimes palatalized (realized as [S]) before the high front vowel /i/. 
The consonantal inventory is nearly identical to the one described by Kauczor and Drexel (1930). The only differences are that these authors considered the flap a separate phoneme, and they had identified three words with an $h$. These words were possibly loans from Arabic. The allophony of the dental and alveolar stops, as well as the absence of a voiceless bilabial stop except as a word-final allophone, confirm the findings here in striking detail.

These findings were in contrast to Stevenson's quite distinctive findings in Nyimang. Stevenson identified many contrasts that were significant in Nyimang but not in Afitti. The specific distinctions he identified include a contrast between dental and alveolar stops, the independent phonemes $/ \mathrm{g} /$ and $/ \mathrm{p} /$, as well as two different $r$ sounds that are analyzed here as allophones of a single phoneme.

\section{The Vowel System}

Table 5 illustrates the vowels of Afitti. The symbols in parentheses represent prominent allophones of the phoneme beside which they appear. The vowel system also contrasts significantly with the system of Nyimang.

\section{Table 5. The Afitti vowel system (allophones in brackets)}

$\begin{array}{lccc} & \text { front } & \text { central } & \text { back } \\ \text { high } & \mathrm{i}(\mathrm{l} / \mathrm{i}) & & \mathrm{u}(\mathrm{v}) \\ \text { mid } & \mathrm{e}(\varepsilon) & \partial & \mathrm{o}(\mathrm{o}) \\ \text { low } & & \mathrm{a}(\mathrm{a}) & \end{array}$

Notably, the vowel system of Afitti does not possess the [ATR] distinction suggested for Nyimang. Closed syllables consistently show the more centralized vowel allophones of /o/, /u/, /i/ and /e/. Apart from some variation in vowel quality between speakers, however, the variations are predictable.

The high front vowel /i/ has an additional centralized allophone, which is found in closed syllables and in syllables closed with [r]. Most speakers also use a less centralized allophone in other closed syllables. The distinction between centralized /i/ and the other vowels can be clearly heard, but it is sometimes difficult to differentiate the centralized allophone from the schwa /a/, the sixth vowel in the system. Below are illustrated some of these allophones.

$\begin{array}{lll}\text { [wùdíg] } & \text { /wùdíg/ } & \text { 'kursan tree' } \\ \text { [tégə̀l] } & \text { /tégàl/ } & \text { 'gold' } \\ \text { [’̀r] } & \text { /òr/ } & \text { 'head' }\end{array}$




$\begin{array}{lll}\text { [àcóṕ] } & \text { /àcúb/ } & \text { 'three' } \\ \text { [nòkór] } & \text { /nòkór/ } & \text { 'north' } \\ \text { [téndìk] } & \text { /téndìk/ } & \text { 'saddle' } \\ \text { [kòríkòrí'] } & \text { /kòríkòrí/ } & \text { 'spoon' (made of shell) }\end{array}$

The schwa does not occur in word-initial or word-final position, and although it may be seen as a reduced version of some of the other vowels in other cases, it does form minimal pairs with other vowels, justifying its analysis as a distinct phoneme. The examples below illustrate some minimal pairs.

\begin{tabular}{|c|c|}
\hline $\begin{array}{l}\text { (2) /kòrí/ } \\
\text { /kórì/ }\end{array}$ & $\begin{array}{l}\text { 'woman' } \\
\text { 'straw (reed)' }\end{array}$ \\
\hline $\begin{array}{l}\text { /bàtá/ } \\
\text { /bátá/ }\end{array}$ & $\begin{array}{l}\text { 'neck' } \\
\text { 'speech' }\end{array}$ \\
\hline $\begin{array}{l}\text { /tórà/ } \\
\text { /tárà/ }\end{array}$ & $\begin{array}{l}\text { 'shelter' } \\
\text { 'watering hole' }\end{array}$ \\
\hline
\end{tabular}

Vowels are relatively short in Afitti with some lengthening occurring in stressed syllables. Furthermore, vowels are shorter in closed syllables than in open syllables. The schwa, however, is always short and limited in distribution, never being found in word-final position. It remains short when the syllable is stressed, as shown by the examples in (3a) and in such cases the consonant that follows it may be geminated, as in the second example in (3a). It is not yet certain if this process may also explain the geminate /1/; only one word with a geminate $/ 1 /$ was found but it followed [a], as shown in (3b).
a. /cácòr/ ['cóccòr] 'straight' /tòtว̀bán/ ['tòttว̀bán] 'tree (wide or thick)'
b. /òràllá/
'the past'

Combinations of two vowels are common and include combinations where the second vowel is schwa. There are no diphthongs; the vowels are given individual tones and are analyzed as forming the nuclei of different syllables. Such sequences are presented in (4a) and (4b) separated by semi-vowels that are frequently audible as well (see discussion below). 


$\begin{array}{lll}\text { a. } & \text { /àréyò/ } \\ \text { /lòwàtŕ/ } & \begin{array}{l}\text { 'pregnant' } \\ \text { 'to pass by' }\end{array} \\ \text { b. } & \text { /tówàl/ } & \text { 'thigh' } \\ & \text { /táwàl/ } & \text { 'filter (made of cloth)' } \\ \text { /túwòl/ } & \text { 'to bury' }\end{array}$

Kauczor and Drexel describe a wide variation in vowel quality and identify the phonological environments that condition the variants. Their final set of vowel phonemes, however, consists of only five vowels; it excludes the schwa but the result is otherwise similar to the analysis above. Although they analyze the schwa as predictable (and derived) in some morphophonological environments, there remain oppositions where the vowel contrasts with other vowels.

Stevenson, on the other hand, analyzes as phonemic many of the more centralized allophones as well as the schwa. He also identifies contrastive vowel length, which in this analysis is predictable and thus not contrastive, the same analysis put forward by Kauczor and Drexel (1930).

\section{Semi-vowels and Labialization}

The semi-vowels $[\mathrm{w}]$ and $[-\mathrm{y}]$ are of questionable phonemic status. They are (phonetically) present between vowels or in word-initial position preceding a vowel. The palatal [-y] is also heard in final position as an allophone of $/ \mathrm{i} /$ following another vowel, e.g., [kátày] 'catch!'. Individual variation indicates that glides are not mandatory with the exception of the final $[-y]$, an allophone of $/ \mathrm{i} /$. The presence of either $[\mathrm{w}]$ or $[-\mathrm{y}]$ is thus predictable, and no phonologically distinctive role may be established.

Labialization, however, is a secondary feature similar to palatalization, as discussed above. Afitti features labialized nasals and consonants but only velar stops and velar and palatal nasals, as shown below.

$$
\begin{array}{ll}
\text { /kwàrtá/ } & \text { 'old' } \\
\text { /kwòcán/ } & \text { 'empty, hollow' } \\
\text { /ywódà/ } & \text { 'male animal' } \\
\text { /ángwà/ } & \text { 'porridge of maize' }
\end{array}
$$

Labialization was found only before $/ \mathrm{a} /, / \mathrm{o} /$ and $/ \mathrm{u} /$ and did not appear consistently with each speaker. Thus, even as a secondary feature, the status of $[\mathrm{w}]$ is uncertain.

Yet some words are consistently pronounced using a semi-vowel or a labialized consonant and not all occurrences are predictable. 
(6)

$\begin{array}{ll}\text { /éwèn/ } & \text { 'full' } \\ \text { /àwíl/ } & \text { 'bag' } \\ \text { /táyà1/ } & \text { 'giraffe' }\end{array}$

Because of these facts the introduction of $/ \mathrm{w} /$ and $/ \mathrm{y} /$ into the phonology of the language has some justification. Where consistently produced, a semi-vowel needs to be indicated.

Kauczor and Drexel (1930) present $/ \mathrm{w} /$ and $/ \mathrm{y} /$ as phonemes and do not treat labialized consonants as separate phonemes. The variation in labialization for consonants across speakers was also noted by Stevenson. In the analysis presented here, the solution proposed by Kauczor and Drexel has been followed.

\section{Tone and Stress}

Afitti is a tone language with stress. Tonal minimal pairs are attested for monosyllabic, bisyllabic and trisyllabic words, but in longer words stress seems to play a more important role. Some (near) minimal pairs are presented below.

(7)

$\begin{array}{llll}\text { /tŕ/ } & \text { 'stand still' } & \text { /tr̀/ } & \text { 'vagina' } \\ \text { /ór/ } & \text { 'market' } & \text { /òr/ } & \text { 'head' } \\ \text { /ílà/ } & \text { 'maid' } & \text { /ílá/ } & \text { 'cough' } \\ \text { /àtá/ } & \text { 'pus' } & \text { /átá/ } & \text { 'hand' } \\ \text { /tòndó/ } & \text { 'take it' } & \text { /tóndò/ 'blind man' } \\ \text { /kàsír/ } & \text { 'shepherd' } & \text { /kásìr/ 'to be tired' } \\ \text { /mógórà/ } & \text { 'leopard' } & \text { /mògòrá/ 'chairman' } \\ \text { /kúrúmà/ } & \text { 'finger' } & \text { /kúrùmá/ 'big ant' }\end{array}$

Informants corrected longer words for stress rather than for tonal patterns, accepting different tonal patterns but insisting that stress remain fixed. The stressed syllable is marked by a combination of duration, volume and change in tone, rather than just tone alone.

$\begin{array}{ll}\text { dunagorto' ragəni } & \text { 'they became fat' } \\ \text { isəlolitə'ragəni } & \text { 'they hung up' } \\ \text { kadə'kotay } & \text { 'we lift' }\end{array}$


Perhaps more curious is the absence of a third tone, since it is prominent in Nyimang and other neighboring languages. Afitti has only two phonemic tones with strong and clear downdrift, with no third tone or even downstep. In the first example the final tone is realized as a mid tone because of downdrift. In the second example the two initial tones are phonetically mid tones because they are low tones at the beginning of an utterance before downdrift has lowered them. Similarly to the first example the final tone lowers due to downdrift.

(9) /tálèngá/ 'north'

Phonetic tonal pattern: ["-] high-low-mid

/ìrìíṫ̀rí/ 'make a ball'

Phonetic tonal pattern: $\left[^{--\cdots-}\right]$ mid-mid-high-low-mid

Tonal pattern when $/ \mathrm{a} /$ is not pronounced:

/ìrìítrì/ $\left[{ }^{--’}\right]$ mid-mid-high-low

The shortening of syllables ending in $/ \mathrm{r} /$ has lead to many words that have a syllabic $/ \mathrm{r} /$ or an intervocalic flap following a schwa. The schwa is omitted altogether by some speakers reducing the word by one syllable and possibly eliminating a tone. This reduction does not lead to downstep for a following tone. Instead, one tone is assimilated to the neighboring tone, keeping the tonal pattern intact, i.e., when a few low tones are followed by a high tone, only a low tone is omitted and not the final high, and vice versa.

Certain (phonetic) tone sequences have been used to argue for the presence of a third tone in related languages, or at least require an explanation if a two-tone system is assumed, because they cannot be explained by downdrift alone. For a three-syllable word, four such sequences are possible and yet none of the suspicious sequences were attested in Afitti:

['-'] high-mid-low, ['-'] low-mid-high,

[' '] ] low-high-mid, ['' '] mid-low-high

In "short" words, those consisting of fewer than five syllables, stress can be placed on different syllables as long as the tonal pattern remains in place. Since stress commonly coincides with a change in tone it is not clear whether the tonal system is complicated by stress in long words or a tone system is being reduced to a stress system. Both low and high tone syllables (first and second examples) and also the schwa (third example) may carry stress. 
(10)

$\begin{array}{ll}\text { kùrmìdìmá'kòtán } & \text { 'I will trip' } \\ \text { kùrmìdì'mótàn } & \text { 'we will trip' } \\ \text { kadə'kətay } & \text { 'he/she lifts' }\end{array}$

As shown above, tonal minimal pairs can be identified for both monosyllabic and polysyllabic words. So far no sets have been found that distinguish all four two-tone configurations in two-syllable words, i.e., high-high, low-low, high-low and low-high. The most common patterns in two syllable words feature a change in tone, one of the last two patterns HL or LH.

Tone and stress are still insufficiently studied for Afitti because the morphology and syntax of the language are still not understood. It is clear though that a third tone does not need to be established, another bit of of analysis also advanced by Kauczor and Drexel. It must nonetheless be remarked as an oddity since most neighboring languages feature a third tone.

\section{Syllable Structure}

Afitti has both closed and open syllables. Syllables may be closed with a nasal, a liquid or a stop. Single-segment syllables may consist of a vowel, a (syllabic) liquid or a (syllabic) nasal. Syllables include combinations of consonant and vowel but few consonant clusters.

(11)

$\begin{array}{ll}\text { màrsák } & \text { 'spear' } \\ \text { àcúp } & \text { 'three' } \\ \text { wùník } & \text { 'scorpion' } \\ \text { bíbùt } & \text { 'Wednesday' } \\ \text { tàrbón } & \text { 'tears' } \\ \text { kòrtás } & \text { 'pepper' (<Arabic) } \\ \text { àgór } & \text { 'man' } \\ \text { bòldín } & \text { 'sling (weapon)' } \\ \text { kól } & \text { 'fat' }\end{array}$

Nasals that precede consonants are always syllabic - there are no prenasalized segments or nasal-consonant sequences. Liquids that follow consonants or fricatives are preceded by a schwa for most speakers, but in many cases are realized (exceptionally) as consonant clusters. Nasals do not follow other consonants and there are no tautosyllabic consonants that follow liquids or fricatives. 
Words usually contain one, two or three syllables, but verbs may contain as many as eight or more (as seen above).

\section{Regional Features and Nyimang}

The above description of Afitti phonology is markedly different from descriptions of nearby and related Nyimang. Vowel length, a third tone, dental stops and labialization are rare, non-contrastive, or even absent, in Afitti. Although syllabic $/ \mathrm{r} /$ and /1/ have been attested in Nyimang (Tucker and Bryan 1966:243), the phonological status of the intervocalic flap remained unclear to both Stevenson and Rilly (pers. comm. 2007).

Even though Nyimang is Afitti's closest neighbor, few speakers stated that they could speak the language or were familiar with the language other than by name. Instead, Afitti is surrounded by Kordofan Nubian and Arabic speakers. The intervocalic flap, the absence of $/ \mathrm{r} /$ in word-initial position but also the allophones $[\mathrm{s}]$ and $[\delta]$ are attested in neighboring Tagle, a Kordofan Nubian language spoken near Jebel el-Dair (Ibrahim \& Huttenga 2007). Indeed, the voicing distinction for plosives that is mostly lost in intervocalic position is mentioned as an areal feature by Schadeberg (1987).

In short, the closest linguistic neighbor Nyimang may have confused some linguists working on both Afitti and Nyimang. However, Afitti is not immune to areal influences and has been influenced lexically and phonologically by its closest geographical neighbors. For the purpose of establishing a writing system for Afitti, the analysis above should contribute to the decision-making process.

\section{Acknowledgements}

The author wishes to thank Claude Rilly and several anonymous reviewers for their valuable comments and insight, as well as Jennifer Steffy for her helpful art work. Particular thanks is owed to Vincent Francigny, Haider Ahmed Ali, Mohammed al-Bakr, Baha'adin Merghani Mekki and his family in ar-Rahad, as well as the Afitti speaking community in Kundukur, in particular Sheikh Ibrahim and Gasim Raghal Baadi Ajib, without whom this research would not have been possible.

The research was made possible by the generous support of the Society for the Advancement of Research in the Tropics (Treub-Mij.). 


\section{References}

Bender, Lionel M., 2000. Roland Stevenson's Nyimang and Dinik lexicon. Afrikanistische Arbeitspapiere 63: 103-120.

Bolton, A.R.C., 1936. The Dubab and Nuba of Jebel Daier. Sudan Notes and Records 19: 93-108.

Greenberg, Joseph H. 1963. The languages of Africa. Bloomington: Indiana University Press.

Ibrahim, G. \& P. Huttenga. 2007. The phoneme system of Tagle, a Kordofan Nubian language. In Doris L. Payne \& Mechtild Reh (eds.), Advances in NiloSaharan Linguistics, pp. 99-113. Cologne: Rüdiger Köppe.

Kauczor, P. D. 1923. The Affiti Nuba of Gebel Dair and their relationship to the Nuba people. Sudan Notes and Records 6: 1-34.

Kauczor, Daniel \& Albert Drexel. 1930. Die Daiersprache in Kordofan. Bibliotheca Africana 4(1): 67-78, 4(2): 42-53.

MacDiarmid, P.A. \& D.N. MacDiarmid. 1931. The languages of the Nuba Mountains. Sudan Notes and Records 14: 149-162.

Rilly 2004. The linguistic position of Meroitic. Arkamani, Sudan Electronic Journal of Archaeology and Anthropology. http://www.arkamani.org/arkamanilibrary/meroitic/rilly.htm

Rottland, Franz \& Angelika Jakobi. 1991. Loanword word evidence from the Nuba mountains: Kordofan Nubian and the Nyimang group. In Ulrike Claudi \& Daniela Mendel (eds.), Ägypten in Afro-Orientalischen Kontext. Aufsätze zur Archaeologie, Geschichte und Sprache eines unbegrenzten Raumes. Gedenkschrift Peter Behrens Afrikanistische Arbeitspapiere, Sondernummer 1991, pp. 249-269. Cologne: AAP.

Schadeberg, Thilo C. 1987. Zwei areale Sprachmerkmale im Ostsudan. In: Hans G. Mukarovsky (ed.), Leo Reinisch: Werk und Erbe. Vienna: Österreichische Akademie der Wissenschaften.

Stevenson, Robert C., 1957. A survey of the phonetics and grammatical structure of the Nuba mountain languages. Afrika und Ubersee XLI: 171-196.

Stevenson, Robert C. 1962. Linguistic research in the Nuba mountains I. Sudan Notes and Records 43: 118-130. 
Stevenson, Robert C. 1964. Linguistic research in the Nuba mountains II. Sudan Notes and Records 45: 79-102.

Stevenson, Robert C. 1984. The Nuba People of Kordofan Province. An Ethnographic Survey. London: Ithaca Press.

Stevenson, Robert C., Franz Rottland \& Angelika Jakobi. 1992. The verb in Nyimang and Dinik. Afrikanistische Arbeitspapiere 32: 5-64.

Thelwall, Robin \& Thilo C. Schadeberg, 1983. The linguistic settlement of the Nuba mountains. Sprache und Geschichte in Afrika 5: 219-231.

Tucker, Archibald Norman \& M.A. Bryan, 1956. The non-Bantu languages of North-Eastern Africa, pp. 62-63. Oxford: Oxford University Press.

Tucker, Archibald Norman \& M.A. Bryan, 1966. Linguistic analyses: the nonBantu languages of North-Eastern Africa, pp. 243-252. Oxford: Oxford UniversityPress.

American Museum of Natural History Central Park West at 79th Street

New York, New York 10024-5192

adevoogt@amnh.org submitted 11 Aug 09

resubmitted 16 Dec 09

accepted 15 Jan 10 